\title{
CHANGES IN THE AMOUNT OF SOLUBLE CARBOHYDRATES AND POLYPHENOLS CONTENTS DURING DECOMPOSITION OF Montrichardia arborescens (L.) SCHOTT.
}

\author{
Marcela Bianchessi da CUNHA-SANTINO ${ }^{1}$, Lucilia Dias PACOBAHYBA ${ }^{1}$, \\ Irineu BIANCHINI JR., ${ }^{1,2}$
}

\begin{abstract}
This study describes the aerobic and anaerobic decay of soluble carbohydrates $(\mathrm{CH})$ and polyphenols $(\mathrm{PH})$ during decomposition of Montrichardia arborescens. Plant and water samples were collected in the Cantá stream $\left(2^{\circ} 49^{\prime} 11^{\prime \prime} \mathrm{N}\right.$ and $\left.60^{\circ} 40^{\prime} 24^{\prime \prime} \mathrm{W}\right)$, Roraima, Brazil. Decomposition chambers with plant fragments and stream water were incubated. Particulate organic matter was separated from dissolved organic matter and concentrations of $\mathrm{CH}$ and $\mathrm{PH}$ were determined. The results were fitted to $1^{\text {st }}$ order kinetics models. $\mathrm{CH}$ and $\mathrm{PH}$ comprised a labile fraction ( $\mathrm{LCH}$ and $\mathrm{LPH}$ ) and a refractory fraction ( $\mathrm{RCH}$ and $\mathrm{RPH})$. The global coefficient associated with LCH weight loss was 1.4 times higher under aerobic conditions ( 3.4 day $\left.^{-1}\right)$ higher than for anaerobic conditions. On the other hand, the $\mathrm{RCH}$ decay rate in the anaerobic process $\left(0.0074\right.$ day $\left.^{-1}\right)$ was 1.39 times higher. $\mathrm{LCH}$ was estimated to be $92 \%$ while $\mathrm{RCH}$ amounted to $8 \%$. The LPH anaerobic decay was 5.2 times the value for the aerobic decay $\left(0.67\right.$ day $\left.^{-1}\right)$. For both conditions, RPH decay coefficients were similar $\left(\approx 0.011\right.$ day $\left.^{-1}\right)$. In the aerobic experiments LPH and RPH corresponded to $92.5 \%$ and $7.5 \%$, respectively. For the anaerobic process these contents were $85.5 \%$ and $14.5 \%$, respectively. From these results, we concluded that in the Cantá stream, the anaerobic degradation of phenols is more efficient than the aerobic counterpart. The aerobic condition provides a faster decay of carbohydrates of this plant.
\end{abstract}

Key-words: carbohydrates, polyphenols, aerobic and anaerobic decomposition, Montrichardia arborescens.

\section{Variação dos teores de carboidratos e de polifenóis solúveis durante a decomposição de Montrichardia arborescens, (L.) Schott.}

RESUMO - Este estudo descreveu o decaimento aeróbio e anaeróbio de carboidratos $(\mathrm{CH})$ e polifenóis (PH) durante a decomposição de Montrichardia arborescens. As amostras de planta

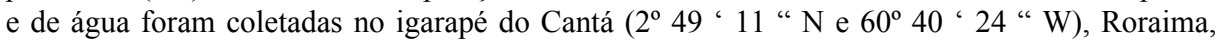
Brasil. Câmaras de decomposição contendo fragmentos de plantas e água do iguarapé foram incubadas. A matéria orgânica particulada foi separada da dissolvida e as concentrações $\mathrm{CH}$ e $\mathrm{PH}$ foram determinadas. Os resultados foram ajustados a um modelo cinético de $1^{\mathrm{a}}$ ordem. $\mathrm{O} \mathrm{CH} \mathrm{e}$ o PH apresentaram duas frações: uma lábil ( $\mathrm{LCH}$ e LPH) e uma refratária (RCH e RPH). Verificouse que o coeficiente global relacionado com a perda de massa do LCH para condição aeróbia $(3,4$ dia $^{-1}$ ) foi 1,4 vezes mais elevado que para a anaeróbia. Por outro lado, o coeficiente de decaimento do $\mathrm{RCH}$ para o processo anaeróbio $\left(0,0074 \mathrm{dia}^{-1}\right)$ foi 1,39 vezes mais elevado. O LCH foi estimado em $92 \%$ e o refratário em $8 \%$. A degradação anaeróbia de LPH foi 5,2 vezes mais elevada que a aeróbia $\left(0,67 \mathrm{dia}^{-1}\right)$. Os coeficientes de decaimento do RPH foram similares $\left(\approx 0,011 \mathrm{dia}^{-1}\right)$ para ambas condições. Para o experimento aeróbio, o LPH e o RPH corresponderam a 92,5\% e 7,5\%. Para os processos anaeróbios estas frações foram de $85,5 \%$ e $14,5 \%$, respectivamente. A partir

${ }^{1}$ Programa de Pós Graduação em Ecologia e Recursos Naturais, Universidade Federal de São Carlos, Rodovia Washington Luis, km 235, CEP: 13565-905, Caixa Postal 676. São Carlos, SP, Brasil. E-mail: mbcunha@cosmo.com.br

${ }^{2}$ Universidade Federal de São Carlos, Departamento de Hidrobiologia, Rodovia Washington Luis, km 235, CEP: 13565-905, Caixa Postal 676. São Carlos, SP, Brasil. E-mail: irineu@power.ufscar.br 
destes resultados, supõe-se que no igarapé do Cantá, a degradação anaeróbia dos polifenóis seja mais eficiente que a aeróbia. A condição aeróbia promove um decaimento mais rápido dos carboidratos desta planta.

Palavras-chave: carboidratos, polifenóis, decomposição aeróbia e anaeróbia, Montrichardia arborescens.

\section{INTRODUCTION}

Photosynthesis is the process by which organisms convert light into chemical energy and use these chemicals to drive carbon fixation and sugar production (Bowyer \& Leegood, 1997). The sugars thus produced provide raw material for biosynthesis of all the organic molecules found in plants. Phenols are important as cellular support materials; they form an integral part of cell wall structures, mainly in polymeric materials such as lignin, providing mechanical support (Strack, 1997). Another organic compound responsible for this support is cellulose, which is a structural carbohydrate formed by a long, linear sequence of D-glucose residues joined together by $\beta(1 \rightarrow 4)$ glycosyl linkages. Many carbohydrates in the cell wall serve as reserve material, e. g. starch and sucrose among others (Grant Reid, 1997). These organic compounds can enter in the aquatic ecosystem with the loss of cellular integrity, during senescence and death of aquatic macrophytes. In aquatic systems, carbohydrates and polyphenols range from dissolved organic matter (DOM) to large aggregates of particulate organic matter (POM). DOM consists of different organic compounds, many of which may serve as microbial substrates. These compounds comprise dissolved free amino acids, carbohydrates (Bunte \& Simon, 1999), polypeptides, lipids, polyphenolic compounds and humic substances (Hessen, 1992). POM contains mostly cellulose and lignin (Cunha \& Bianchini Jr., 1998).

Decomposition of POM and DOM results in gaseous end products. POM can be converted enzymatically or chemically to soluble organic compounds by microflora. Decomposition of organic matter in aquatic ecosystems is driven by the nature of the organic matter and the supply of electron acceptors.
In the Amazon area the aquatic macrophytes are found in large quantities and wide diversity (Rodrigues, 1989), which make them important for the energy and matter fluxes. Although several studies on decomposition of aquatic macrophytes exist in Brazil, only scant data can be found for the Amazon area. This work is aimed at describing and discussing the kinetics of decomposition of carbohydrates $(\mathrm{CH})$ and polyphenols $(\mathrm{PH})$ during the cycling of DOM and POM from Montrichardia arborescens assessed under both aerobic and anaerobic conditions.

\section{MATERIALS AND METHODS}

Montrichardia arborescens (L.) Schott. is a typical plant of flooded areas with a height of 2-4 $\mathrm{m}$. This aquatic macrophyte species is popularly known as aninga and belongs to the Araceae family. It is usually found in the Amazon area and Northeast of Brazil (Rodrigues, 1989). Samples of water and plants (adults samples) were collected in the Cantá stream, municipal district of Cantá $\left(02^{\circ} 49^{\prime} 11^{\prime \prime}\right.$ $\mathrm{N}$ and $60^{\circ} 40^{\prime} 24^{\prime \prime} \mathrm{W}$ ), in the State of Roraima, Brazil. The plants were washed in the stream; in laboratory, these plants were washed with tap water to remove the periphyton, sediment particles and coarse material. After being washed the plant material was oven-dried $\left(45^{\circ} \mathrm{C}\right)$ and triturated; the fragments of leaves, stems and stalks were homogeneized. The water samples were filtered with glass wool to remove coarse particles. For decomposition experiments, the plant material $\left(10 \mathrm{~g} \mathrm{l}^{-1} \mathrm{DW}\right)$ was added to the samples of the stream water. The flasks ( $\mathrm{n}=10$ for each condition) were maintained in the dark, at room temperature $\left(26.3^{\circ} \mathrm{C} \pm 0.32\right)$ under aerobic conditions (by bubbling air) and anaerobic conditions. Based on the kinetics of oxygen consumption described for this resource and on the maximum 
amount of available dissolved oxygen in each chamber $\left(\approx 3.25 \mathrm{mg}=[\mathrm{OD}]_{\text {sat }}{ }^{\prime} 0.41\right.$; where $[O D]_{\text {sat }}$ at $26.3^{\circ} \mathrm{C} \approx 8.11 \mathrm{mg} \mathrm{l}^{-1}$ ), the mixtures were considered to become anaerobic $2 \mathrm{~h}$ after adding the plant fragments. After 1, 3, 5, 10, $15,20,30,60,90$ and 120 days, the flask contents were fractionated into dissolved organic matter (DOM) and particulate organic matter (POM) by pre-filtration in nylon mesh (pore diameter $=0.4 \mathrm{~mm}$ ) followed by centrifugation (1 h, 978.2 g). Subsamples of DOM and POM were used to measure the concentrations of soluble carbohydrate $(\mathrm{n}=3)$ and polyphenol $(n=2)$; these determination were based on colorimetric methods according to the procedures prescribed in Dubois et al. (1956) and Bianchini Jr. \& Toledo (1981). Extraction of $\mathrm{CH}$ and $\mathrm{PH}$ from $\mathrm{POM}$ of the par-
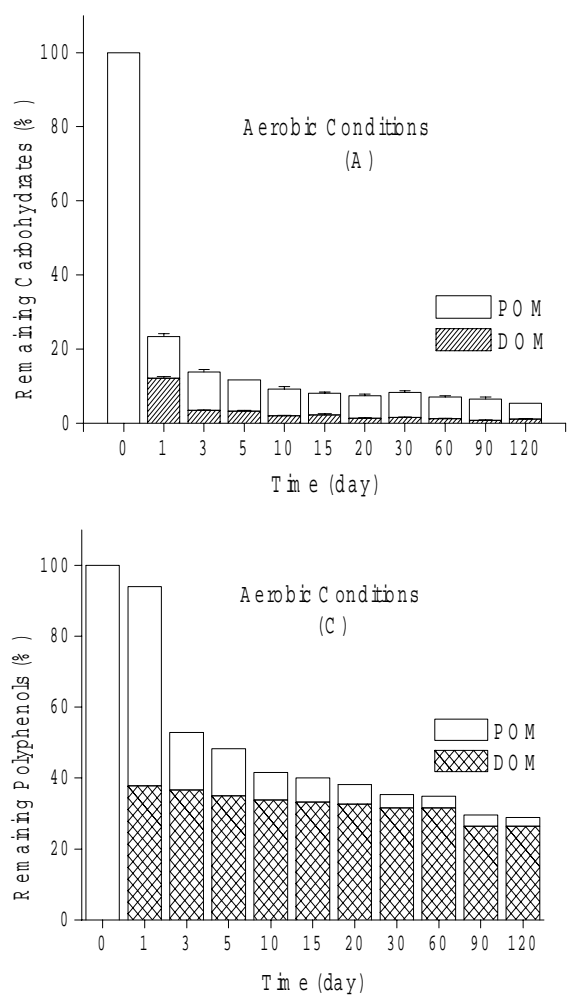

ticulate detritus was made with ammonium oxalate $(0.5 \%)$ and methanol (50\%), respectively.

\section{RESULTS AND DISCUSSION}

The changes in the amount of soluble $\mathrm{CH}$ and $\mathrm{PH}$ over a 120-day period are shown in Figure 1, which brings the remaining fractions of dissolved (DCH and DPH) and particulate $(\mathrm{PCH}$ and $\mathrm{PPH})$ detritus. The greatest losses in the first 24-h of decomposition was noted for $\mathrm{CH}$ under both conditions. In terms of percentages of the initial biomass, after 1 day $\mathrm{PCH}=88.82 \%$ and $\mathrm{DCH}$ $=87.82 \%$ for aerobic process and $\mathrm{PCH}=$ $83.72 \%$ and $\mathrm{DCH}=94.65 \%$ for the anaerobic condition.

For PH there was less significant de-
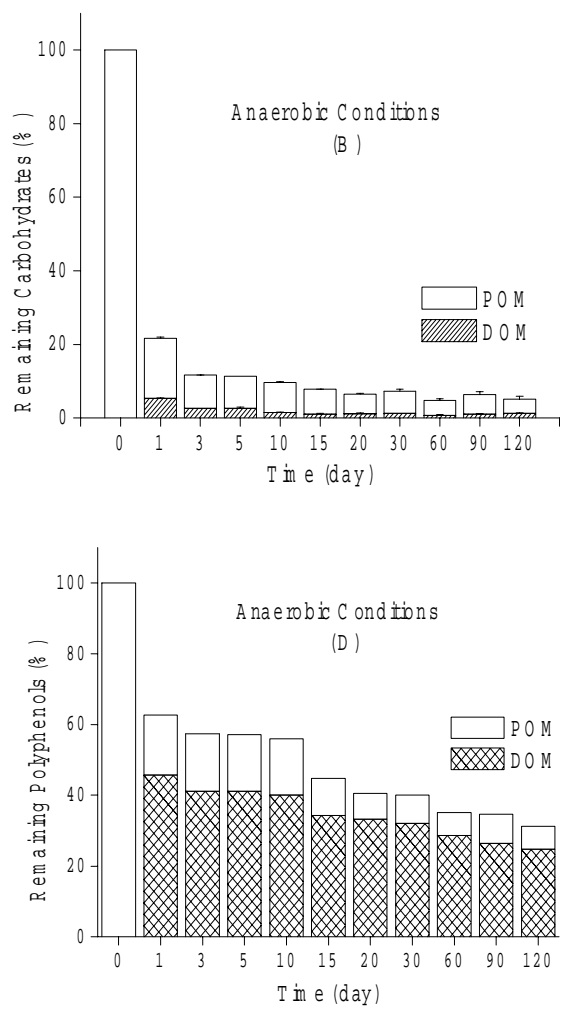

Figure 1 - Percentile of remaining carbohydrates (A and B) and polyphenols (C and D) during aerobic and anaerobic decomposition from M. arborescens. 
crease in concentrations in the early stage of decomposition than carbohydrates. For instance, after one day $\mathrm{PPH}=43.74 \%$ and $\mathrm{DPH}$ $=62.22 \%$ for the aerobic condition, and for the anaerobic process $\mathrm{PPH}=83.01 \%$ and $\mathrm{DPH}=$ $54.28 \%$. In contrast, the accelerated de composition for $\mathrm{DCH}$ and $\mathrm{PCH}$ is related to the chemical structure of monomers sequences linked by glycosyl bonds that facilitate the microbial attack (Hurst \& Burges, 1967). On the other hand, polyphenols are characterized by at least one aromatic ring (6C) bearing one or more hydroxyl groups. The benzene nucleus is one of the commonest chemical structures found in natural organic products (Strack, 1997). Three modes of aromatic ring cleavage by microorganisms have been described: i) ortho-cleavage pathway, ii) meta-cleavage pathways and gentisate pathways (Dagley, 1986). Phenols are relatively stable structures that require high amounts of energy to be cleaved (Walker, 1975), resulting in the low uptake of $\mathrm{PH}$ in comparison with $\mathrm{CH}$.

The results of remaining $\mathrm{CH}$ and $\mathrm{PH}$ were fitted to first-order kinetics model (Bianchini Jr., 1997; Higgins \& Walker, 2001). This model considers that the rates are proportional to substrate concentrations and combines equations describing leaching and mineralization (Equations 1-3). The parameterization of aerobic and anaerobic $\mathrm{CH}$ and $\mathrm{PH}$ decay is summarized in Table 1.

The decrease in $\mathrm{CH}$ and $\mathrm{PH}$ concentra-

$$
\begin{aligned}
& I N_{1}=\frac{k_{M}}{k_{1}} P O M_{L}\left(1-e^{k_{1} t}\right) \\
& I N_{2}=\frac{k_{L}}{k_{1}} P O M_{L}\left(1+\frac{k_{2}}{k_{1}-k_{2}} e^{-k_{1} t}+\frac{k_{1}}{k_{2}-k_{1}} e^{-k_{2} t}\right) \\
& I N_{3}=\operatorname{POM}_{R}\left(1-e^{-k_{3} t}\right)
\end{aligned}
$$

where:

$$
\begin{aligned}
& \mathrm{POM}_{\mathrm{L}}=\mathrm{Labile} / \mathrm{solub} \text { le particu late organic m atter (LPCH Or LPPH); } \\
& \text { POM } R=\text { Refractory particu late organ ic matter (RPCH orRPPH); } \\
& \mathrm{DOM}=\mathrm{D} \text { is solved organ ic matter: } D O M=\frac{k_{L}}{k_{1}} P O M_{L} \quad \text { (DCH OrDPH); } \\
& \text { t }=\mathrm{T} \text { im e; } \\
& \mathrm{k}_{1}=\mathrm{POM}_{\mathrm{L}} \mathrm{globaldecay} \text { coefficient }\left(\mathrm{k}_{\mathrm{L}}+\mathrm{k}_{\mathrm{M}}\right) \text {; w here: } \mathrm{k}_{\mathrm{L}}=\mathrm{POM} \\
& \text { leachate coeffic ient and } \mathrm{k}_{\mathrm{M}}=\mathrm{POM} \mathrm{M}_{\mathrm{L}} \mathrm{m} \text { ineralization coeffic ient; } \\
& \mathrm{k}_{2}=\mathrm{DOM} \mathrm{m} \text { ine ralization coeffic ient; } \\
& \mathrm{k}_{3}=\mathrm{POM}_{\mathrm{R}} \mathrm{m} \text { in era lization coeffic ient; } \\
& \mathbb{N}_{1 a_{3}}=\text { Inorgan ic com pounds produced fro } \mathrm{m} \text { the three } \mathrm{m} \text { inera lization routes. }
\end{aligned}
$$


Table 1 - Parameters of the aerobic and anaerobic decomposition of carbohydrates and polyphenol from $M$. arborescens. Where: $\mathrm{k}_{1}=$ coefficient of leachate/product formation + mineralization $\left(\mathrm{k}_{1}=\mathrm{k}_{\mathrm{L}}+\mathrm{k}_{\mathrm{M}} \mathrm{k}_{\mathrm{L}}=\right.$ leaching coefficient and $\mathrm{k}_{\mathrm{M}}=$ labile $\mathrm{CH}$ or PH mineralization coefficient); $\mathrm{k}_{2}=$ decay coefficient of DCH or DPH; $\mathrm{k}_{3}=$ decay coefficient of RPCH or RPPH; $\mathrm{LPCH}$ and LPPH = labile fractions of particulate carbohydrates and polyphenols; RPCH and $\mathrm{RPPH}=$ refractory fractions of particulate carbohydrates and polyphenols; DCH and DPH $=$ fractions of dissolved carbohydrate and polyphenols. $\mathrm{IN}=$ yields of $\mathrm{CH}$ and $\mathrm{PH}$ decay products; $\mathrm{IN}_{1}=$ from $\mathrm{LPCH}$ or LPPH; $\mathrm{IN}_{2}=$ resulting from $\mathrm{DCH}$ or $\mathrm{DPH}$ and $\mathrm{IN}_{3}=$ from $\mathrm{RPCH}$ or RPPH.

\begin{tabular}{|c|c|c|c|c|c|c|c|}
\hline \multicolumn{8}{|c|}{ Yields (\%) and Coefficients $\left(\right.$ day $\left.^{-1}\right)$} \\
\hline & & \multicolumn{2}{|c|}{ Carbohydrates } & & & \multicolumn{2}{|c|}{ Polyphenols } \\
\hline & & Aerobic & Anaerobic & & & Aerobic & Anaerobic \\
\hline $\mathrm{LPCH}$ & $=$ & 91.9 & 91.9 & LPPH & $=$ & 92.54 & 85.48 \\
\hline $\mathrm{RPCH}$ & $=$ & 8.1 & 8.1 & $\mathrm{RPPH}$ & $=$ & 7.46 & 14.52 \\
\hline $\mathrm{DCH}$ & $=$ & 17.27 & 5.06 & DPH & $=$ & 38.74 & 41.75 \\
\hline $\mathbb{I N}_{1}$ & $=$ & 74.63 & 86.84 & $\mathbb{I N}_{1}$ & $=$ & 53.80 & 43.73 \\
\hline $\mathbb{I N}_{2}$ & $=$ & 17.27 & 5.06 & $\mathrm{IN}_{2}$ & $=$ & 38.74 & 41.75 \\
\hline $\mathrm{IN}_{3}$ & $=$ & 8.1 & 8.1 & $\mathrm{IN}_{3}$ & $=$ & 7.46 & 14.52 \\
\hline $\mathrm{k}_{1}$ & $=$ & 3.4 & 2.4 & $\mathrm{k}_{1}$ & $=$ & 0.67 & 3.48 \\
\hline $\mathrm{k}_{2}$ & $=$ & 0.4704 & 0.1140 & $k_{2}$ & $=$ & 0.0040 & 0.0053 \\
\hline $\mathrm{k}_{3}$ & $=$ & 0.0053 & 0.0074 & $k_{3}$ & $=$ & 0.0129 & 0.0101 \\
\hline
\end{tabular}

tions was nonlinear with time, presenting a biphasic decay pattern that points to a heterogeneous compound from the kinetics point of view. These organic compounds presented two fractions: a labile (LCH and $\mathrm{LPH})$ and a refractory $(\mathrm{RCH}$ and $\mathrm{RPH})$ one. The kinetics model allowed us to identify three decay pathways for $\mathrm{CH}$ and $\mathrm{PH}$ : (i) the labile fractions of $\mathrm{CH}$ and $\mathrm{PH}$ are changed quickly $\left(\mathrm{k}_{1}\right)$. Simultaneously, the second pathway $\left(\mathrm{k}_{1}\right)$ is a transformation of LPCH into dissolved (DCH and $\mathrm{DPH})$. In the sequence, this fraction breaks down according to $\mathrm{k}_{2}$. In the third route, there is a slow change in the refractory fraction ( $\mathrm{RCH}$ and $\mathrm{RPH})$ occurs $\left(\mathrm{k}_{3}\right)$.

During aerobic and anaerobic $\mathrm{CH}$ decomposition, the labile fractions were estimated to be $92 \%$ and the refractory fraction was $8 \%$. The coefficient $\mathrm{k}_{1}$ is related to $\mathrm{LCH}$ decay. For aerobic decomposition it was 3.4 day $^{-1}, 1.4$ times the value for the anaerobic process $\left(2.4\right.$ day $\left.^{-1}\right)$. Decomposition of Montrichardia arborescens is dominated by an abiotic process of leaching during the initial 12$\mathrm{h}$ to 1 -d (Bianchini Jr. et al., 2002). This process is accomplished by the loss of many soluble organic substances (e. g. $\mathrm{CH}$ and $\mathrm{PH}$ ) and labile materials from the protoplasmatic fraction of plant material. The decay coefficient $\mathrm{k}_{1}$ is governed by the nature of the plant tissues, e.g. type and amount of organic compound released in leaching. Dissolved carbohydrates $(\mathrm{DCH})$ represent $5.06 \%$ for the anaerobic process and $17.27 \%$ for the aerobic one. These fractions changed according $\mathrm{k}_{2}$, which was 0.96 day $^{-1}$ and 0.344 day $^{-1}$ for the aerobic and anaerobic conditions, respectively. The $\mathrm{RCH}$ mineralization rate, $\mathrm{k}_{3}$, was 0.0074 day $^{-1}$ for the anaerobic process, 1.39 times higher than the aerobic value. This coefficient was related with the solubilization and oxidation of lignocellulosic residues.

In the aerobic decomposition experiments, the PH contents of detritus of LPH and RPH corresponded to $92.5 \%$ and $7.5 \%$, respectively. For the anaerobic process these fractions were $85.5 \%$ and $14.5 \%$, respectively. Higher coefficients of LPH consumption $\left(\mathrm{k}_{1}\right)$ occurred during the anaerobic decomposition of M. arborescens $\left(3.48 \mathrm{day}^{-1}\right)$, while under aerobic conditions this rate was 5.2 times lower $\left(0.67\right.$ day $\left.^{-1}\right)$. During leaching of LPPH, DPH 
is produced and mineralized according to $\mathrm{k}_{1}$. Under aerobic conditions, $\mathrm{k}_{2}$ for the DPH decay mineralizatin rate was 0.011 day $^{-1}$ and for the anaerobic process this value was 0.0009 day $^{-1}$. These fractions represent $41.75 \%$ in the anaerobic process and $38.74 \%$ in the aerobic one. $\mathrm{RPH}$ decay rates $\left(\mathrm{k}_{3}\right)$ were similar for both conditions $\left(\approx 0.011\right.$ day $\left.^{-1}\right)$.

The effect of the microbial degradation in the regulation of carbohydrate and polyphenol concentrations in the Cantá stream is directly associated with the $\mathrm{k}^{\prime} \mathrm{s}\left(\mathrm{k}_{1}, \mathrm{k}_{2}\right.$ and $\mathrm{k}_{3}$ from Table 1). It is supposed that the labile fraction of these compounds with high decomposition rates, with an average $\mathrm{k}_{1}$ for aerobic and anaerobic conditions being 2.9 day $^{-1}$ for $\mathrm{CH}$ and 2.07 $\mathrm{day}^{-1}$ for $\mathrm{PH}$, have a greater potential for biodegradability than the refractory fractions. For the latter, the average $\mathrm{k}_{3}$ for anaerobic and aerobic conditions was 0.0064 day $^{-1}$ for $\mathrm{CH}$ and $0.0115 \mathrm{day}^{-1}$ for $\mathrm{PH}$. Overall, the high values of k's for the labile fractions probably indicate that carbohydrates and polyphenols do not tend to accumulate in the Cantá stream. On the other hand, the refractory fractions presented low k's and remained unaffected for a long time $\left(\mathrm{t}_{1 / 2}\right.$ : $\mathrm{CH}=108$ days and $\mathrm{PH}=60$ days). The $\mathrm{k}_{\mathrm{s}}$ from the model (Table 1) suggest that the anaerobic decomposition of LPH was more effective than the aerobic, and that the aerobic condition provides a faster decomposition for $\mathrm{CH}$ of $M$. arborescens.

\section{ACKNOWLEDGEMENTS}

The authors thank Coordenadoria de Aperfeiçoamento de Pessoal de Nível Superior (CAPES) for partial support of this research. We are also indebted to Dr. Osvaldo N. Oliveira Jr. (IFSC-USP) for his critical proof reading of the manuscript.

\section{LITERATURE CITED}

Bianchini Jr., I.; Toledo, A. P. P. 1981. Determinação de compostos fenólicos com reagente de Folin-Denis. Ciênc. Cult., 33(4): 576-577.
Bianchini Jr., I.; Pacobahyba, L. D. a CunhaSantino, M. B. 2002. Aerobic and anaerobic decomposition of Montrichardia arborescens (L.) Schott. Acta Limnol. Brasil., 14(3): 27-34.

Bianchini, Jr., I. 1997. The degradation process of organic matter in reservoirs. In: Rosa, L. P.; Santos, M. A. (eds.). Hydropower Plants and Greenhouse Gas Emissions. Editora Tecnologica, Rio de Janeiro.

Bowyer, J. R.; Leegood, A. R. C. 1997. Photosynthesis. In: Dey, P. M., Harborne, J. B. (eds). Plant Biochemistry. Academic Press, San Diego, p. 49-110.

Bunte, C.; Simon, M. 1999. Bacterioplankton turnover of dissolved free monosaccharides in a mesotrophic lake. Limnol. Oceanogr., 44(8): 1862-1870.

Cunha, M. B.; Bianchini Jr., I. 1998. Cinéticas de mineralização aeróbia de celulose e lignina durante a degradação de Cabomba piauhyensis e Scirpus cubensis. Acta Limnol. Brasil., 10(2): 59-69.

Dagley, S. 1986. Catabolism of aromatic compounds by micro-organisms. Adv. Ecol. Res., 15:1-48.

Dubois, M.; Gilles, K.; Hamilton, J. K.; Rebers, P. A.; Smith, F. 1956. Colorimetric method for determination of sugar and related substances. Anal. Chem., 28: $350-356$.

Hessen, D. O. 1992. Dissolved organic carbon in a humic lake: effect on bacterial production and respiration. Hydrobiol., 229:115-123.

Higgins, C. W.; Walker, L. P. 2001. Validation of a new model for aerobic organic solids decomposition: simulations with substrate specific kinetics. Proc. Biochem., 36:87584.

Hurst, H. M.; Burges, N. A. 1967. Lignin and Humic Acids. In: Mclaren, A. D., Peterson, G.H. (eds.). Soil Biochemistry. Marcel Dekker, New York, p. 260-286. 
Grant Reid, J. S. 1997. Carbohydrate Metabolism: Structural Carbohydrates In: Dey, P. M., Harborne, J. B. (eds.), Plant Biochemistry. Academic Press, San Diego, p. 205-236.

Rodrigues, R. M. 1989. A Flora Amazônica. Ed. CEJUP, Belém, 462p.
Strack, D. 1997. Phenolic Metabolism. In: Dey, P. M., Harborne, J. B. (eds.), Plant Biochemistry. Academic Press, San Diego, p. 205-236.

Walker, R. L. 1975. The biology of plant phenolics. Edward Arnold Limited, Baltimore, 57p. 
